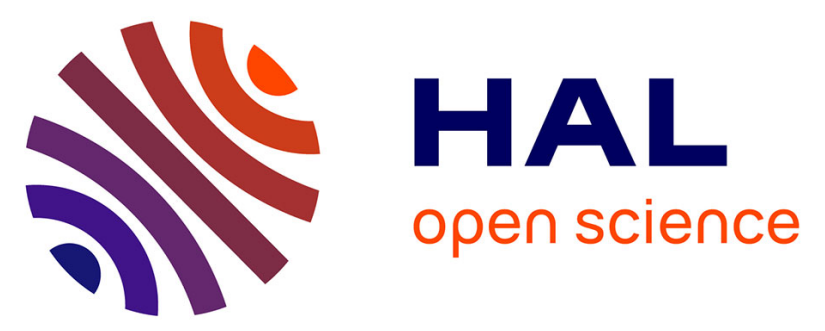

\title{
Economic Burden of Metastatic Clear-Cell Renal Cell Carcinoma for French Patients Treated With Targeted Therapies
}

Tiphaine Cholley, Antoine Thiery-Vuillemin, Samuel Limat, Marion Hugues, Fabien Calcagno, Guillaume Mouillet, Amélie Anota, Virginie Nerich

\section{To cite this version:}

Tiphaine Cholley, Antoine Thiery-Vuillemin, Samuel Limat, Marion Hugues, Fabien Calcagno, et al.. Economic Burden of Metastatic Clear-Cell Renal Cell Carcinoma for French Patients Treated With Targeted Therapies. Clinical Genitourinary Cancer, 2019, 17, pp.e227 - e234. 10.1016/j.clgc.2018.10.016 . hal-03486384

\section{HAL Id: hal-03486384 https://hal.science/hal-03486384}

Submitted on 20 Dec 2021

HAL is a multi-disciplinary open access archive for the deposit and dissemination of scientific research documents, whether they are published or not. The documents may come from teaching and research institutions in France or abroad, or from public or private research centers.
L'archive ouverte pluridisciplinaire HAL, est destinée au dépôt et à la diffusion de documents scientifiques de niveau recherche, publiés ou non, émanant des établissements d'enseignement et de recherche français ou étrangers, des laboratoires publics ou privés.

\section{(c)(1) $\$$}

Distributed under a Creative Commons Attribution - NonCommerciall 4.0 International 


\section{Economic burden of metastatic clear-cell renal cell carcinoma for French patients treated with targeted therapies}

Tiphaine Cholley ${ }^{1}$, Antoine Thiery-Vuillemin ${ }^{2,3}$, Samuel Limat ${ }^{1,3}$, Marion Hugues ${ }^{1}$, Fabien Calcagno $^{2,3}$, Guillaume Mouillet ${ }^{1}$, Amélie Anota $^{4,5}$, Virginie Nerich ${ }^{1,3^{*}}$

1 - Department of Pharmacy - University Hospital - Besançon - France

2 - Department of Medical Oncology - University Hospital - Besançon - France

3 - INSERM, EFS BFC, UMR1098, Interactions hôte-greffon-tumeur - Ingénierie

Cellulaire et Génique - University Bourgogne Franche-Comté - Besançon - France

4 - Quality of Life in Oncology National Platform - Besançon - France

5 - Methodological and Quality of Life in Oncology Unit (INSERM UMR 1098) -

University Bourgogne Franche-Comté University Hospital - Besançon - France

*Corresponding author:

Virginie NERICH, Pharm.D, PhD

Department of Pharmacy

University Hospital

Boulevard Fleming

25030 BESANCON Cedex

Email:v1nerich@chu-besancon.fr

Phone: +33 370632286 - Fax: +33 370632424

Conflict of interest :

Dr Thiery-Vuillemin Antoine and Dr Mouillet Guillaume serve as consultants for different companies. Amelie Anota received non-financial support from companies. But these conflicts of interest are not directly related to the content of the article.

Other authors declare that they have no conflict of interest. 


\section{ABSTRACT}

Background: Targeted therapies have transformed the treatment of metastatic clear-cell renal cell carcinoma (mccRCC). Despite the importance of mccRCC, studies evaluating its economic burden in daily practice are sparse. The purpose of this retrospective study was to evaluate cost-of-illness for 224 patients with diagnosed mccRCC included in the cohort published by Thiery-Vuillemin et al., and then to determine the explanatory factors of costof-illness.

Methods: The study was performed from the French Public Healthcare System perspective with lifetime horizon. Only direct medical costs were included. Multiple linear regression was used to search for explanatory factors of cost-of-illness. The robustness of results was assessed.

Results: The mean cost-of-illness was estimated at $€ 71,185 \pm 52,683$. Outpatient/inpatient treatment and hospitalization represented $76.0 \%$ and $19.7 \%$ of this cost, respectively. After adjustment, five explanatory factors were identified: time of disease control for the metastatic first-line treatment $\geq 6$ months, number of lines of treatment $>2$, nephrectomy at metastatic stage, lack of metastases at presentation, age at metastatic diagnosis $<65$ years. Individually, they increased cost-of-illness by $128 \%, 95 \%, 53 \%, 53 \%$ and $23 \%$, respectively.

Conclusions: Although it is difficult to transpose our EE results to those obtained in other countries, it should be noted that our findings were consistent with them and robust. To our knowledge, our study was the first to accurately identify explanatory factors of cost-ofillness. Identifying them could enable us to predict the budgetary impact on a regional level of managing patients who began their first-line treatment with a targeted therapy.

Key words: cost-of-illness; explanatory factors, metastatic clear-cell renal cell carcinoma; targeted therapy. 


\section{Funding sources}

This research did not receive any specific grant from funding agencies in the public, commercial, or not-for-profit sectors.

\section{Background}

Kidney cancer accounts for 3.4\% of all newly diagnosed cancers, with an overall estimate of 115,174 cases, causing 48,991 deaths (5.0\%) in Europe for the year 2012 [1]. It is the third most frequent urologic cancer after prostate and bladder cancers [1]. Among various histologic entities of kidney cancers, clear-cell carcinoma is the most common accounting for approximately $70 \%$ of renal-cell carcinomas (RCC) [2]. To date, nine targeted therapies (through inhibition of angiogenesis or the mTOR pathway) have been evaluated in randomized, controlled phase III clinical trials in patients with metastatic RCC, and they have been approved by regulatory authorities in Europe [3-11]. Large randomized studies have shown significant benefit with targeted therapies, which has been confirmed by various cohorts [12-14].

These targeted therapies have transformed the treatment of metastatic clear-cell RCC (mccRCC) and have largely outperformed cytokines as the first-line standard of care [1417].

On the other hand, clinical and economic studies in daily practice are sparse [18-27]. A previous retrospective multicenter study was conducted to assess the effectiveness of targeted therapies in real life settings [28]. All patients with histologically confirmed mccRCC who received targeted therapies in first-line treatment were included. Three prognostic factors influencing overall survival were identified in first-line treatment: MSKCC favorable and intermediate risks, metastasectomy and lack of lymph node metastasis). In second-line treatment, three different prognostic factors predicted long survival: toxicity for first-line treatment, time of disease control in first-line and MSKCC favorable and intermediate risks. These real-life data not only confirmed the positive impact of targeted therapies in the mccRCC setting, but also highlighted the importance of considering many factors to better estimate patient prognosis. 
Antineoplastic drugs have had a major and growing impact on health insurance expenditures. In France, in 2015, antineoplastic drug expenditure for inpatients reached $€ 1,696$ million, targeted therapies representing more than $54 \%$ of this figure (€923 million) [29]. In comparison, antineoplastic drug expenditure for outpatients, reimbursed by the general fund - which covers $85 \%$ of the French population - reached $€ 1,646$ million (i.e. $8.6 \%$ of overall drug expenditure for outpatients) and targeted therapies represented $€ 885$ million [29,30]. In 2015, 5.1\% and 4.4\% of antineoplastic drug expenditure for outpatient treatment were respectively associated with everolimus and sunitinib, both being used to treat patients with mccRCC [29].

In the context of rational decision-making in health care, the economic evaluation (EE) of health care products has become a necessity. One of the major challenges is to provide cost-effectiveness data that are relevant to daily practices and may be required to optimize consumption of healthcare resources. Decision-making for coverage and reimbursement of new drugs is being increasingly supported by EE in many countries including Australia, Canada, and the UK [31,32]. Furthermore, it's essential to estimate the economic burden of cancer and its management. However, despite the importance of mccRCC, data concerning its economic burden are few. Thus, the purpose of this retrospective study was to evaluate the cost-of-illness for 224 patients with diagnosed mccRCC included in the cohort published by Thiery-Vuillemin et al., and then to determine the explanatory factors of costof-illness [28].

\section{Patients and Methods}

\section{Patient population and treatment}

From January 2007 to March 2015, all consecutive patients with histologically confirmed mccRCC who started their first-line treatment with a targeted therapy in 3 main oncology treatment sites of the Institut Régional Fédératif du Cancer de Franche-Comté were included in the analysis The selection procedure of 224 patients with histologically confirmed mecRCC who started their first line treatment with a targeted therapy was previously presented by Thiery Vuillemin et al.[28]. Each anticancer drug was given until disease progression, toxicity or death and was routinely administered according to 
guidelines and the summary of product characteristics. Some patients might have received drugs as part of clinical trial; in that case, drug was given following the clinical study protocol.

\section{Cost-of-illness study}

This EE was performed from the French Public Healthcare System perspective. Only direct medical costs, from the start of metastatic first-line treatment until death from any cause or to last follow-up for survivors (lifetime horizon), were included in our analysis, i.e. costs related to outpatient and inpatient treatment, hospitalization, outpatient consultations and healthcare travel. Minor costs and costs considered to be independent of the treatment were not taken into account (such as premedication, outpatient treatment of adverse events). Nor were indirect medical and intangible costs. Costs are expressed in Euros $(€)$ (reference year 2015). All of these cost items were collected by reviewing each patient's medical and pharmaceutical records, completed by the French hospital discharge system for hospitalization data.

\section{Inpatient and outpatient treatment}

For reimbursed drugs administered in hospital (bevacizumab, temsirolimus) and ambulatory (axitinib, everolimus, pazopanib, sorafenib, sunitinib, cytokine and interferon) settings, we determined the exact number of milligrams per prescription and per patient and then multiplied this quantity by the purchase price of each drug. Unit prices of drugs were obtained from wholesale price lists from our hospital and from official tariffs for outpatient treatment.

\section{Hospitalization}

We identified each hospitalization for nephrectomy, anticancer drug administration, serious adverse event management, radiotherapy, metastasectomy and best supportive care. Hospital resource costs were based on the French public Diagnosis-Related Group (DRG) database, which is used to fund each hospital stay and does not include expensive drugs such as bevacizumab and temsirolimus (http://atih.sante.fr). All resources were therefore 
included for each hospital with the exception of these expensive drugs. For instance, the DRG for chemotherapy is estimated at €410.67.

\section{Outpatient consultations}

An outpatient consultation was performed every month for each patient ( $€ 28$, according to the French Public Healthcare System) (http://ameli.fr).

\section{Healthcare travel}

Healthcare travel costs were estimated for each patient based on the total number of hospital admissions and the number of outpatient consultations. Patient traveling costs were based on one return trip by light medical vehicle per hospital admission or outpatient consultation, using the distance from home to hospital, according to the French Public Healthcare System (http://ameli.fr).

\section{Base case and sensitivity analyses}

Because direct medical costs were measured over a period exceeding one year for the majority of patients, an annual discount rate was applied at a $4 \%$ annual rate according to recommendations of the department of Economics and Public Health Assessment of the French Haute Autorité de Santé [33].

The robustness of the cost-of-illness study, i.e. the base-case result, was assessed through a series of deterministic one-way sensitivity analyses. Firstly, the anticancer drugs are the most important cost driver of cost-of-illness; thus, the cost of each reimbursed anticancer drug was reduced by $30 \%$, but also increased by $30 \%$ to take into account the potential advent of generic anticancer drugs onto the European market in future years as well as intra-country price variability. Secondly, an annual discount rate of $0 \%$ and 5\% were used instead of $4 \%$ to take into account uncertainty related to the basic methodological choice and transferability of results.

\section{Statistical analysis and determination of the explanatory factors of cost-of-illness}

Continuous variables were described by mean \pm standard deviation and range, and qualitative variables by size and percentage. The Wilcoxon rank-sum test (Mann-Whitney 
U test) or the Kruskal-Wallis test was used to compare continuous variables. Association between quantitative variables was measured on the Spearman rank-order correlation, nonparametric measure of association based on the ranks of data values (Spearman correlation coefficient $(\theta)$, p-value).

Multiple linear regression was used to search for explanatory factors of cost-of-illness for patients with diagnosed mccRCC (patient-related variables, mccRCC-related variables and treatment-related variables). To determine which variables were candidates for explanatory factors of cost-of-illness in multiple linear regression, their association with cost-of-illness was previously explored in a univariate way using the Mann-Whitney $U$ test and the Spearman rank-order correlation, like the correlation between candidate variables. All variables with $p<0.15$ entered into the multiple linear regression. The data was tested for the assumption of normality for the variable of cost-of-illness using the Shapiro-Wilk test. If the distribution is found to be skewed, this may lead to problems with statistical estimation such as heteroscedasticity in the model. Thus, the natural logarithm of cost-ofillness was used as the dependent variable for further analyses. Because the dependent variable was log-transformed, the coefficient estimates are semi-elasticities for which coefficient interpretation requires some care. Thus, for a dichotomous explanatory variable, such as MSKCC risk group (favorable $=1$ and intermediate/poor $=0$ ), the coefficient estimate represents the factor by which cost would be higher or lower for the favorable risk as opposed to the intermediate/poor risk. By exponentiating the estimated coefficient and subtracting 1 , it is possible to interpret the result as a percentage change from the reference group. Using the delta method, we estimated and reported the standard error associated with the estimated coefficient for the switching status variable (explanatory variable) $[33,34]$.

All tests were two-tailed and significant at an alpha threshold of 5\% (p). Statistical analysis was performed with $\mathrm{SAS}^{\circledR}$ software version 9.1.3.

Several variables were then studied to determine their impact on cost-of-illness. They included:

- patient characteristics: gender (female versus male), age at metastatic diagnosis (< 65 versus $\geq 65$ years); 
- metastases at presentation (yes versus no);

- MSKCC prognostic risk (favorable versus intermediate versus poor, favorable or intermediate versus poor) at metastatic diagnosis;

- $\quad$ nephrectomy at metastatic stage (yes versus no);

- metastasectomy (yes versus no);

- $\quad$ radiotherapy (yes versus no);

- participation in therapeutic clinical trial (yes versus no);

- injectable metastatic first-line treatment (yes versus no);

- time of disease control (defined by the time interval between initiation of treatment to progression of disease) for the metastatic first-line treatment ( $<6$ versus $\geq 6$ months);

- Number of metastatic lines of treatment (1 or 2 versus $>2)$.

The robustness of the base-case model was assessed through a series of deterministic oneway sensitivity analyses, the same as for the cost-of-illness study. 


\section{Results}

\section{Cost-of-illness study}

The mean cost-of-illness of 224 patients with diagnosed metastatic clear-cell renal cell carcinoma was estimated at $€ 71,185 \pm 52,683$ with a range from $€ 1,235$ to $€ 263,405$ (Table 1). Interestingly, outpatient/inpatient treatment and hospitalization represented $76.0 \%$ and $19.7 \%$ of this cost, respectively. The mean cost of first-line treatment was estimated at $39,843 \pm 36,253 €$, i.e. $56.0 \%$ of the cost-of-illness (Table 2). The deterministic one-way sensitivity analysis confirms the robustness of these results, with the economic impact of the cost of reimbursed anticancer drugs (Table 3).

\section{Explanatory factors of cost-of-illness}

Results of the univariate analysis are summarized in Table 4. Seven potential explanatory factors were significantly associated with higher cost-of-illness: MSKCC prognostic risk at metastatic diagnosis ( $\mathrm{p}$-value $<0.0001)$, time of disease control for the metastatic first-line treatment ( $\mathrm{p}$-value $<0.0001)$, number of metastatic lines of treatment ( $\mathrm{p}$-value $<0.0001)$, metastasectomy $(\mathrm{p}$-value $=0.003)$, metastases at presentation $(\mathrm{p}$-value $=0.02)$, nephrectomy at metastatic stage $(p$-value $=0.08)$ and age at metastatic diagnosis $(p$-value $=$ $0.10)$.

After adjustment, multiple linear regression with log-transformed cost-of-illness as the dependent variables demonstrated significant associations between time of disease control for the metastatic first-line treatment $\geq 6$ months, number of lines of treatment $>2$, nephrectomy at metastatic stage, lack of metastases at presentation, age at metastatic diagnosis $<65$ years and cost-of-illness (Table 5). Individually, they increased cost-ofillness by $128 \%( \pm 22), 95 \%( \pm 19), 53 \%( \pm 19), 53 \%$ ( \pm 17$)$, and $23 \%( \pm 12)$, respectively, explaining up to $47 \%$ of cost-of-illness variability. Thus, the extent of cost-of-illness can range from $€ 15,465$ (lack of explanatory factors) to $€ 198,670$ (all explanatory factors). 


\section{Discussion}

Despite the importance of mccRCC, studies evaluating its economic burden are sparse [18-27]. Most of them were conducted before 2011 and before targeted therapies appeared on the market [18-22]. However, targeted therapies for mccRCC have brought both new hope and new challenges, considerably expanding the number of treatment options for this indication. Because we have come to question the clinical and economic impact of systematically/routinely using these targeted therapies for patients with mccRCC, we decided to assess their effectiveness and cost-of-illness [28]. Thus, all patients with mccRCC treated over an eight-year period in three main oncology treatment centers of our Franche-Comté region were included in this retrospective study. It has estimated a mean cost-of-illness of $€ 71,185 \pm 52,683$, to look at it against mean follow-up time after treatment initiation estimated at $25.6 \pm 23.6$ months $[0.3-111.1]$, i.e. around $€ 2,780$ per patient per month, from the payer's perspective. Indirect and intangible medical costs were not taken into account as costs for loss of productivity were not included. Because of this, the cost-of-illness may have been underestimated. Nevertheless, it seems unlikely given the mean age at metastatic diagnosis of patients $(67 \pm 11$ years $)$. The largest cost driver of cost-of-illness was inpatient and outpatient anticancer treatment (76\% of cost-of-illness). The second largest cost driver was hospital stays (20\% of cost-of-illness). The cost of firstline treatment represented $56 \%$ of cost-of-illness.

Few EE conducted in Europe and North America have estimated the economic burden of mccRCC for patients treated with targeted therapies [23-27]. In France, in 2013, Maroun et al. assessed the economic burden among patients with mccRCC treated by targeted therapies from first-line of treatment to the last follow-up or death, from a hospital perspective, at $€ 22,318$ (year 2013) [23]. Only $16 \%$ (against $63 \%$ in our study) of patients had received at least one administration of bevacizumab or temsirolimus; this can explain the difference with our results taking into account only hospital costs (around $€ 30,000$ ). Four years later, in 2017, Maroun et al. assessed direct medical costs from the payer's perspective among patients with mccRCC treated in first-line by targeted therapies, from treatment initiation until the last follow-up or death [24]. Patient characteristics (age at metastatic diagnosis, gender and sites of metastases) are similar to those of our patient 
cohort, except for MSKCC risk group which was unknown. Direct medical costs were estimated at $€ 5,546$ (i.e. year 2016) per patient per month and treatment costs reached $€ 2,327$ per patient per month. In comparison with our study, supplementary costs, i.e. laboratory and imagery were included which, again, may explain the difference with our results (€71,185 with a follow-up of 25.6 months or $€ 2,780$ per patient per month). Both the first and second cost drivers were cost treatment (in- and outpatient) and hospitalization, representing $46 \%$ and $40 \%$ of total cost, respectively. We identified these same cost-drivers. Differences in terms of patient distribution among MSKCC group risk can account for the discrepancy in the results of the two studies.

Although it is difficult to transpose our EE results to those obtained in other countries, using the same inclusion and exclusion criteria, perspective and lifetime horizon, it should be noted that our findings were consistent with them [25-27]. Thus, a Dutch study published in 2017 by De Groot et al. estimated mean cost-of-illness at €65,620 $\pm 11,031$ (year 2014). Supplementary costs (only healthcare travel) in our study can explain the observed difference [25]. A Canadian study published in 2016 by Nazha et al. estimated the mean treatment cost of the first three lines of treatment (taking into account only drug acquisition and hospitalisation for administration) with targeted therapy at $\$ 100,078$ (i.e. $€ 83,629$, year 2016) from the payer's perspective [26].

It is not surprising to find treatment as the first cost-driver, as previous EE identified treatment as the main cost-driver for overall mccRCC burden [24,27]. Thus, for example, Choueri et al. performed a retrospective review of patients treated with an angiogenesis inhibitor in first-line treatment in two tertiary oncology centres in the United States [27]. They concluded that first-line treatment cost (i.e. year 2008) for patients treated with sunitinib, sorafenib and bevacizumab represented $71 \%, 74 \%$ and $90 \%$ of cost-of-illness, respectively. This cost included out- and inpatient treatment, hospitalization, outpatient consultations and healthcare travel.

It should be noted that sensitivity analysis showed robustness of results. Indeed, knowing that treatment is the main cost-driver, variation in the cost of treatment has a direct impact on overall cost. Thus, robustness of results makes it possible to minimize the impact of intra-country price variability over time, taking into account the potential advent of generic anticancer drugs on the market in the years to come. 
Not surprisingly, the cost of first-line treatment is the highest when compared with other lines of treatment, correlated to the duration of first-line treatment. Indeed, increasing overall survival brings about an increase in the cost of treatment. Moreover, this result was expected given the fact that nephrectomy is recommended in mccRCC treatment $[35,36]$. Metastasectomy also increased first-line cost, because it was performed for 43 out of 54 patients as first-line treatment. These results are similar to those of international cohorts and in agreement with standard mccRCC treatment [26,37]. Thus, a Canadian study by Nazha et al. showed a lower median cost according to the line of treatment $(\$ 55,986$, $\$ 27,328$ and $\$ 16,764$ (year 2016) in first-, second- and third-line treatment, respectively) [26].

Our results underscore the originality and the strength of our study on the determination of explanatory factors of the economic burden of mccRCC. Additionally, to our knowledge, our study was the first to accurately identify these explanatory factors. The results with high external validity, but low internal validity, identified five explanatory factors: time of disease control for the metastatic first-line treatment $\geq 6$ months (increasing cost-of-illness by $128 \%)$, number of lines of treatment $>2(95 \%)$, nephrectomy at metastatic stage $(53 \%)$, lack of metastases at presentation (53\%) and age at metastatic diagnosis < 65 years $(23 \%)$. Two factors, time of disease control greater than 6 months and lack of metastases at presentation, have already been identified as prognostic factors of overall survival in the Thiery-Vuillemin et al. study [28]. Indeed, improving overall survival could increase the duration of treatment and therefore the cost-of-illness. Likewise, nephrectomy influences overall survival, and consequently the cost-of-illness [38,39]. Interestingly, MSKCC prognostic risk was not related to the cost-of-illness, although it is the main prognostic factor of overall survival in the Thiery-Vuillemin et al. study [28].

Identifying explanatory factors could enable us to develop a dynamic model of the economic burden of mccRCC. Such a model could, in turn, predict the budgetary impact on a regional level of managing patients who began their first-line treatment with a targeted therapy (i.e. Franche-Comté). The findings could then perhaps be extrapolated on the national level, from the French healthcare perspective. Additionally, the model could predict different profiles of patients and enable us to compare their therapeutic strategies. Although this model explains the cost drivers of mccRCC, it does not take into account the 
notion of cost-effectiveness. The perspective of this study is to create a longitudinal model including time effect (through the line of treatment). This model will allow us to conduct an economic analysis to identify the best treatment sequence in patients treated at FrancheComté region. With the advent of immunotherapy on the market and its impact on overall survival, another analysis will be performed to determine its economic impact on the management of patients with mccRCC. 


\section{REFERENCES}

1. Ferlay J, Steliarova-Foucher E, Lortet-Tieulent J, Rosso S, Coebergh JWW, Comber H, et al. Cancer incidence and mortality patterns in Europe: Estimates for 40 countries in 2012. Eur J Cancer. 2013 Apr;49(6):1374-403.

2. American Society Cancer. Kidney cancer (adult) - Renal Cell Carcinoma [Internet]. 2016 [cited 2017 Nov 14]. Available from: https://www.cancer.org/cancer/kidney-cancer/

3. Escudier B, Pluzanska A, Koralewski P, Ravaud A, Bracarda S, Szczylik C, et al. Bevacizumab plus interferon alfa- 2 a for treatment of metastatic renal cell carcinoma: a randomised, double-blind phase III trial. The Lancet. 2007 Dec;370(9605):2103-11.

4. Motzer RJ, Hutson TE, Tomczak P, Michaelson MD, Bukowski RM, Rixe O, et al. Sunitinib versus Interferon Alfa in Metastatic Renal-Cell Carcinoma. N Engl J Med. 2007 Jan 11;356(2):115-24.

5. Escudier B, Eisen T, Stadler WM, Szczylik C, Oudard S, Siebels M, et al. Sorafenib in Advanced Clear-Cell Renal-Cell Carcinoma. N Engl J Med. 2007 Jan $11 ; 356(2): 125-34$.

6. Motzer RJ, Escudier B, McDermott DF, George S, Hammers HJ, Srinivas S, et al. Nivolumab versus Everolimus in Advanced Renal-Cell Carcinoma. N Engl J Med. 2015 Sep 25;373(19):1803-13.

7. Choueiri TK, Escudier B, Powles T, Mainwaring PN, Rini BI, Donskov F, et al. Cabozantinib versus Everolimus in Advanced Renal-Cell Carcinoma. N Engl J Med. 2015 Sep 25;373(19):1814-23.

8. Rini BI, Escudier B, Tomczak P, Kaprin A, Szczylik C, Hutson TE, et al. Comparative effectiveness of axitinib versus sorafenib in advanced renal cell carcinoma (AXIS): a randomised phase 3 trial. The Lancet. 2011 Dec;378(9807):1931-9.

9. Sternberg CN, Davis ID, Mardiak J, Szczylik C, Lee E, Wagstaff J, et al. Pazopanib in Locally Advanced or Metastatic Renal Cell Carcinoma: Results of a Randomized Phase III Trial. J Clin Oncol. 2010 Feb 20;28(6):1061-8. 
10. Hudes G, Carducci M, Tomczak P, Dutcher J, Figlin R, Kapoor A, et al. Temsirolimus, Interferon Alfa, or Both for Advanced Renal-Cell Carcinoma. N Engl J Med. 2007 May 31;356(22):2271-81.

11. Motzer RJ, Escudier B, Oudard S, Hutson TE, Porta C, Bracarda S, et al. Efficacy of everolimus in advanced renal cell carcinoma: a double-blind, randomised, placebocontrolled phase III trial. The Lancet. 2008 Aug;372(9637):449-56.

12. Nerich V, Hugues M, Paillard MJ, Borowski L, Nai T, Stein U, et al. Clinical impact of targeted therapies in patients with metastatic clear-cell renal cell carcinoma. OncoTargets Ther. 2014;7:365-74.

13. Ko JJ, Xie W, Kroeger N, Lee J, Rini BI, Knox JJ, et al. The International Metastatic Renal Cell Carcinoma Database Consortium model as a prognostic tool in patients with metastatic renal cell carcinoma previously treated with first-line targeted therapy: a population-based study. Lancet Oncol. 2015 Mar;16(3):293-300.

14. Soerensen AV, Donskov F, Hermann GG, Jensen NV, Petersen A, Spliid H, et al. Improved overall survival after implementation of targeted therapy for patients with metastatic renal cell carcinoma: Results from the Danish Renal Cancer Group (DARENCA) study-2. Eur J Cancer. 2014 Feb;50(3):553-62.

15. Pal SK, Nelson RA, Vogelzang N. Disease-Specific Survival in De Novo Metastatic Renal Cell Carcinoma in the Cytokine and Targeted Therapy Era. Perez-Gracia JL, editor. PLoS ONE. 2013 May 3;8(5):e63341.

16. Shek D, Tomlinson B, Brown M, Brunson A, Pan C-X, Lara PN. Epidemiologic Trends in Renal Cell Carcinoma in the Cytokine and Post-Cytokine Eras: A Registry Analysis of 28,252 Patients. Clin Genitourin Cancer. 2012 Jun;10(2):93-8.

17. B. Ljungberg, L. Albiges, K. Bensalah, A. Bex, R.H. Giles. European Association of Urology Guideline 2017 - Renal cell cancer [Internet]. European Association of Urology; 2017 [cited 2017 Nov 14]. Available from: http://uroweb.org/guideline/renalcell-carcinoma/ 
18. Shih Y-CT, Chien C-R, Xu Y, Pan I-W, Smith GL, Buchholz TA. Economic burden of renal cell carcinoma: Part I--an updated review. PharmacoEconomics. 2011 Apr;29(4):315-29.

19. Lang K, Danchenko N, Gondek K, Schwartz B, Thompson D. The burden of illness associated with renal cell carcinoma in the United States. Urol Oncol. 2007 Oct;25(5):36875 .

20. Mantovani LG, Morsanutto A, Tosolini F, Mustacchi G, Esti R, Belisari A, et al. The burden of renal cell cancer: A retrospective longitudinal study on occurrence, outcomes and cost using an administrative claims database. Eur J Cancer Suppl. 2008 Oct;6(14):46-51.

21. Geynisman DM, Hu JC, Liu L, Tina Shih Y-C. Treatment Patterns and Costs for Metastatic Renal Cell Carcinoma Patients With Private Insurance in the United States. Clin Genitourin Cancer. 2015 Apr;13(2):e93-100.

22. Gupta K, Miller JD, Li JZ, Russell MW, Charbonneau C. Epidemiologic and socioeconomic burden of metastatic renal cell carcinoma (mRCC): A literature review. Cancer Treat Rev. 2008 May;34(3):193-205.

23. Maroun R, Maunoury F, Benjamin L, Nachbaur G, Durand-Zaleski I. In-Hospital Economic Burden of Metastatic Renal Cell Carcinoma in France in the Era of Targeted Therapies: Analysis of the French National Hospital Database from 2008 to 2013. Bottaro DP, editor. PLOS ONE. 2016 Sep 20;11(9):e0162864.

24. Maroun R, Fleury L, Nachbaur G, Maunoury F, Vanhille J, Durand-Zaleski I. Realworld costs and outcomes in metastatic renal cell carcinoma patients treated with targeted therapies: a cohort study from the French health insurance database. Curr Med Res Opin. 2017 Oct 3;33(10):1755-62.

25. De Groot S, Blommestein HM, Redekop WK, Sleijfer S, Kiemeney LALM, Oosterwijk E, et al. Potential health gains for patients with metastatic renal cell carcinoma in daily clinical practice: A real-world cost-effectiveness analysis of sequential first- and second-line treatments. Postma M, editor. PLOS ONE. 2017 May 22;12(5):e0177364. 
26. Nazha S, Prevost N, Tanguay S, Vanhuyse M. Economic evaluation of targeted therapies in metastatic clear renal cell carcinoma in Canada. In Vienna,Austria; 2016.

27. Choueiri TK, McDermott D, Sheng Duh M, Sarda SP, Neary MP, Oh WK. Costs associated with angiogenesis inhibitor therapies for metastatic renal cell carcinoma in clinical practice: Results from a medical chart review study. Urol Oncol Semin Orig Investig. 2012 Nov;30(6):848-55.

28. Thiery-Vuillemin A, Cholley T, Calcagno F, Hugues M, Maurina T, Limat S, et al. Factors influencing overall survival for patients with metastatic clear-cell renal cellcarcinoma in daily practice. Clin Genitourin Cancer.

29. Institut National du Cancer. Les thérapies ciblées dans le traitement du cancer en 2015 /état des lieux et enjeux [Internet]. Institut National du Cancer; 2016 [cited 2017 Nov 14]. Available from: http://www.e-cancer.fr/Expertises-et-publications/Catalogue-despublications/Les-therapies-ciblees-dans-le-traitement-du-cancer-en-2015-Etat-des-lieux-etenjeux

30. Ministère de la santé. Dépenses de Santé 2015 - Comptes nationaux de la santé 2015 [Internet]. 2016 [cited 2017 Nov 14]. Available from: http://drees.solidaritessante.gouv.fr/etudes-et-statistiques/publications/panoramas-de-la-drees/article/lesdepenses-de-sante-en-2015-resultats-des-comptes-de-la-sante

31. Greenberg D, Earle C, Fang C-H, Eldar-Lissai A, Neumann PJ. When is Cancer Care Cost-Effective? A Systematic Overview of Cost-Utility Analyses in Oncology. JNCI J Natl Cancer Inst. 2010 Jan 20;102(2):82-8.

32. Frederix GWJ, Severens JL, Hövels AM, Raaijmakers JAM, Schellens JHM. The Cloudy Crystal Ball of Cost-Effectiveness Studies. Value Health. 2013 Sep;16(6):1100-2.

33. Haute Autorité de Santé - Department of Economics and Public Health Assessment. Choices in Methods for Economic Evaluation [Internet]. Haute Autorité de Santé; 2012 [cited 2017 Nov 14]. Available from: http://www.has-sante.fr

34. Discrete Multivariate Analysis Theory and Practice [Internet]. New York, NY: Springer New York; 2007 [cited 2017 Nov 14]. Available from: http://link.springer.com/10.1007/978-0-387-72806-3 
35. Flanigan RC, Salmon SE, Blumenstein BA, Bearman SI, Roy V, McGrath PC, et al. Nephrectomy followed by interferon alfa- $2 \mathrm{~b}$ compared with interferon alfa-2b alone for metastatic renal-cell cancer. N Engl J Med. 2001 Dec 6;345(23):1655-9.

36. Mickisch GH, Garin A, van Poppel H, de Prijck L, Sylvester R, European Organisation for Research and Treatment of Cancer (EORTC) Genitourinary Group. Radical nephrectomy plus interferon-alfa-based immunotherapy compared with interferon alfa alone in metastatic renal-cell carcinoma: a randomised trial. Lancet Lond Engl. 2001 Sep 22;358(9286):966-70.

37. Achermann C, Stenner F, Rothschild SI. Treatment, Outcome and Prognostic Factors in Renal Cell Carcinoma - A Single Center Study (2000-2010). J Cancer. 2016;7(8):921-7.

38. Choueiri TK, Xie W, Kollmannsberger C, North S, Knox JJ, Lampard JG, et al. The Impact of Cytoreductive Nephrectomy on Survival of Patients With Metastatic Renal Cell Carcinoma Receiving Vascular Endothelial Growth Factor Targeted Therapy. J Urol. $2011 \mathrm{Jan} ; 185(1): 60-6$.

39. Flanigan RC, Mickisch G, Sylvester R, Tangen C, Van Poppel H, Crawford ED. Cytoreductive Nephrectomy in Patients With Metastatic Renal Cancer: A Combined Analysis. J Urol. 2004 Mar;171(3):1071-6. 
Table 1 Cost-of-illness of 224 patients with diagnosed metastatic clear-cell renal cell carcinoma

\begin{tabular}{lrrr}
\hline Cost items $(€)$ & mean \pm standard deviation & minimum - maximum & percentage \\
\hline Outpatient and inpatient treatment & $54,070 \pm 47,906$ & $673-253,313$ & 76.0 \\
$\quad$ Inpatient treatment & $15,826 \pm 26,586$ & $0-195,339$ & 29.3 \\
Outpatient treatment & $38,244 \pm 45,538$ & $0-253,313$ & 70.7 \\
Hospitalization & $14,016 \pm 9,974$ & $0-42,834$ & 19.7 \\
$\quad$ Nephrectomy & $2,504 \pm 4,297$ & $0-28,265$ & 3.5 \\
Anticancer drug administration & $4,287 \pm 6,668$ & $0-40,870$ & 6.0 \\
Serious adverse event management & $715 \pm 1,934$ & $0-11,936$ & 1.0 \\
Radiotherapy & $730 \pm 1,278$ & $0-6,053$ & 1.0 \\
Metastasectomy & $1,166 \pm 2,383$ & $0-11,273$ & 1.7 \\
Best supportive care & $4,614 \pm 5,557$ & $0-28,789$ & 6.5 \\
Outpatient consultations & $421 \pm 412$ & $0-2,003$ & 0.6 \\
Healthcare travel & $2,679 \pm 2,972$ & $29-17,392$ & 3.7 \\
\hline Cost-of-illness ( $€$ ) & $71,185 \pm 52,683$ & $1,235-263,405$ & 100.0 \\
\hline
\end{tabular}


Table 2 Cost per line of treatment for 224 patients with diagnosed metastatic clear-cell renal cell carcinoma

\begin{tabular}{|c|c|c|c|c|c|}
\hline \multirow{2}{*}{$\begin{array}{l}\text { Line of } \\
\text { treatment }\end{array}$} & \multirow{2}{*}{$\begin{array}{r}\text { Number of } \\
\text { patients } \\
\text { (percentage) }\end{array}$} & \multicolumn{3}{|c|}{ Follow-up (months) } & \multirow{2}{*}{$\begin{array}{c}\text { Cost }(€) \\
\text { minimum - maximum }\end{array}$} \\
\hline & & mean \pm standard deviation & minimum - maximum & mean \pm standard deviation & \\
\hline 1 & $224(100.0)$ & $11.7 \pm 13.0$ & $0.2-109.6$ & $39,843 \pm 36,253$ & $1,235-263,405$ \\
\hline 2 & $189(84.4)$ & $8.1 \pm 9.6$ & $0.1-41.6$ & $22,752 \pm 23,185$ & $1,021-123,933$ \\
\hline 3 & $109(48.7)$ & $6.8 \pm 9.2$ & $0.3-66.9$ & $18,301 \pm 22,030$ & $346-153,155$ \\
\hline 4 & $52(23.2)$ & $5.1 \pm 6.5$ & $0.3-36.6$ & $14,870 \pm 17,036$ & $213-80,603$ \\
\hline 5 & $21(9.4)$ & $6.6 \pm 8.7$ & $0.4-39.8$ & $15,985 \pm 21,674$ & $272-93,897$ \\
\hline 6 & $12(5.4)$ & $3.8 \pm 3.1$ & $0.59-10.6$ & $9,709 \pm 7,361$ & $137-27,714$ \\
\hline 7 & $6(2.7)$ & $2.0 \pm 1.7$ & $0.4-4.8$ & $5,366 \pm 6,108$ & $105-13,796$ \\
\hline 8 & $1(<1.0)$ & 3.1 & l & I & 345 \\
\hline All & $224(100.0)$ & $25.6 \pm 23.6$ & $0.3-111.1$ & $71,185 \pm 52,683$ & $1,235-263,405$ \\
\hline
\end{tabular}

Abbreviation: SD $=$ Standard Deviation 
Table 3 Deterministic one-way sensitivity analysis

Cost-of-illness (€)

\begin{tabular}{lrr}
\hline & & Cost-of-illness $(€)$ \\
\cline { 2 - 3 } & mean \pm standard deviation & minimum - maximum \\
\hline Base-case analysis & $71,185 \pm 52,683$ & $1,235-263,405$ \\
\hline $30 \%$ cost reduction of reimbursed anticancer drugs & $54,964 \pm 38,713$ & $1,033-187,411$ \\
$30 \%$ cost increase of reimbursed anticancer drugs & $87,406 \pm 66,824$ & $1,437-339,399$ \\
Discount rate of 0\% instead of 4\% & $81,565 \pm 68,378$ & $1,237-378,784$ \\
Discount rate of 5\% instead of 4\% & $68,945 \pm 49,539$ & $1,234-241,063$ \\
\hline
\end{tabular}

Abbreviation: $\mathrm{SD}=$ Standard Deviation 
Table 4 Univariate analysis of explanatory factors of cost-of-illness for patients with diagnosed metastatic clear-cell renal cell carcinoma

\begin{tabular}{|c|c|c|c|c|}
\hline \multirow[t]{2}{*}{ Potential explanatory factors } & \multirow{2}{*}{$\begin{array}{r}\text { Number of patients } \\
\text { (percentage) }\end{array}$} & \multicolumn{2}{|r|}{ Cost-of-illness $(€)$} & \multirow[t]{2}{*}{$\mathrm{p}$-value } \\
\hline & & mean \pm standard deviation & minimum - maximum & \\
\hline Gender & & & & 0.67 \\
\hline Male & $159(71.0)$ & $71,646 \pm 55,623$ & $2,250-263,405$ & \\
\hline Female & $65(29.0)$ & $70,056 \pm 45,067$ & $1,235-202,819$ & \\
\hline \multicolumn{5}{|l|}{ Age at metastatic diagnosis, years } \\
\hline Spearman correlation coefficient & $224(100.0)$ & -0.20 & & 0.003 \\
\hline$<65$ & $96(42.9)$ & $79,538 \pm 58,791$ & $1,235-263,405$ & 0.10 \\
\hline$\geq 65$ & $128(54.1)$ & $64,920 \pm 46,859$ & $1,602-238,293$ & \\
\hline Metastases at presentation & & & & 0.02 \\
\hline Yes & $120(53.6)$ & $66,511 \pm 55,382$ & $1,235-244,047$ & \\
\hline No & $104(46.4)$ & $76,578 \pm 49,099$ & $2,370-263,405$ & \\
\hline MSKCC prognostic risk at metastatic diagnosis & & & & $<0.0001$ \\
\hline Favorable & $26(11.6)$ & $93,079 \pm 46,372$ & $34,692-232,084$ & \\
\hline Intermediate & $141(63.0)$ & $76,403 \pm 54,928$ & $2,370-263,405$ & \\
\hline Poor & $57(24.4)$ & $48,292 \pm 41,537$ & $1,235-186,052$ & \\
\hline Favorable or intermediate & $167(74.6)$ & $79,001 \pm 53,902$ & $2,370-263,405$ & \\
\hline Poor & $57(24.4)$ & $48,292 \pm 41,537$ & $1,235-186,052$ & \\
\hline
\end{tabular}




\begin{tabular}{|c|c|c|c|c|}
\hline Nephrectomy at metastatic stage & & & & 0.08 \\
\hline Yes & $68(30.4)$ & $83,300 \pm 60,984$ & $9,219-244,047$ & \\
\hline No & $156(69.5)$ & $65,904 \pm 47,887$ & $1,235-263,405$ & \\
\hline Metastasectomy & & & & 0.003 \\
\hline Yes & $55(24.6)$ & $89,151 \pm 57,188$ & $21,962-263,405$ & \\
\hline No & $169(75.4)$ & $65,338 \pm 49,929$ & $1,235-244,047$ & \\
\hline Radiotherapy & & & & 0.20 \\
\hline Yes & $74(33.0)$ & $74,217 \pm 48,486$ & $13,390-263,405$ & \\
\hline No & $150(67.0)$ & $69,690 \pm 54,730$ & $1,235-244,047$ & \\
\hline Participation in therapeutic clinical trial & & & & 0.26 \\
\hline Yes & $33(14.7)$ & $75,427 \pm 46,734$ & $9,219-232,084$ & \\
\hline No & $191(85.3)$ & $70,452 \pm 53,722$ & $1,235-263,405$ & \\
\hline Injectable metastatic first-line treatment & & & & 0.53 \\
\hline Yes & $99(44.2)$ & $70,986 \pm 56,121$ & $1,235-244,047$ & \\
\hline No & $125(55.8)$ & $71,343 \pm 50,023$ & $1,602-263,405$ & \\
\hline $\begin{array}{l}\text { Time of disease control for the metastat } \\
\text { line treatment, months }\end{array}$ & & & & $<0.0001$ \\
\hline Spearman correlation coefficient & $224(100.0)$ & 0.88 & & \\
\hline$<6$ & $101(45.1)$ & $44,145 \pm 39,732$ & $1,235-232,084$ & \\
\hline$\geq 6$ & $123(54.9)$ & $93,392 \pm 51,737$ & $17,603-263,405$ & \\
\hline
\end{tabular}


Number of metastatic lines of treatment

Spearman correlation coefficient

$224(100.0)$

0.48

1 or 2

$115(51.3)$

109 (48.7)

$51,048 \pm 44,548$

$1,235-263,405$

$>2$

$92,433 \pm 52,433$

$21,664-244,047$

Abbreviations: MSKCC $=$ Memorial Sloan Kettering Cancer Center 
Table 5 Factors associated with cost-of-illness for patients with diagnosed metastatic clear-cell renal cell carcinoma using multiple linear regression analysis

\begin{tabular}{|c|c|c|c|c|c|}
\hline Explanatory factors & $\begin{array}{l}\text { Parameter } \\
\text { estimate } \beta\end{array}$ & $\begin{array}{c}\text { Standard } \\
\text { error } \mathrm{S}_{\beta}\end{array}$ & $\mathrm{p}$-value & $\begin{array}{r}\text { Percentage } \\
\text { Difference } \theta\end{array}$ & $\begin{array}{r}\text { Standard } \\
\text { error } S_{\theta}\end{array}$ \\
\hline \multicolumn{6}{|c|}{ Time of disease control for the metastatic first- } \\
\hline \multicolumn{6}{|l|}{ line treatment, months } \\
\hline$\geq 6$ versus $<6$ & 0.82463 & 0.09848 & $<0.0001$ & 1.28104 & 0.22464 \\
\hline \multicolumn{6}{|c|}{ Number of lines of treatment } \\
\hline$>2$ versus 1 or 2 & 0.66791 & 0.09604 & $<0.0001$ & 0.95016 & 0.18729 \\
\hline \multicolumn{6}{|c|}{ Nephrectomy at metastatic stage } \\
\hline Yes versus no & 0.42591 & 0.12481 & 0.0008 & 0.53098 & 0.19108 \\
\hline \multicolumn{6}{|l|}{ Metastases at presentation } \\
\hline No versus yes & 0.42355 & 0.11378 & 0.0003 & 0.52737 & 0.17378 \\
\hline \multicolumn{6}{|c|}{ Age at metastatic diagnosis, years } \\
\hline$<65$ versus $\geq 65$ & 0.21105 & 0.09677 & 0.0303 & 0.23497 & 0.11951 \\
\hline
\end{tabular}

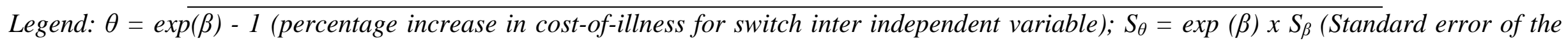
percentage difference) 